Revista de la red interuniversitaria de estudios sobre las literaturas rioplatenses contemporáneas en Francia

$10 \mid 2014$

El XIX en el XX

\title{
El mito de la Cautiva : desplazamientos y proyecciones en la literatura contemporánea argentina.
}

María A. Semilla Durán

\section{OpenEdition}

Journals

Edición electrónica

URL: http://journals.openedition.org/lirico/1708

DOI: 10.4000/lirico.1708

ISSN: 2262-8339

\section{Editor}

Réseau interuniversitaire d'étude des littératures contemporaines du Río de la Plata

Referencia electrónica

María A. Semilla Durán, «El mito de la Cautiva : desplazamientos y proyecciones en la literatura contemporánea argentina. », Cuadernos LIRICO [En línea], 10 | 2014, Puesto en línea el 01 marzo 2014 consultado el 23 abril 2019. URL : http://journals.openedition.org/lirico/1708 ; DOI : 10.4000/ lirico. 1708

Este documento fue generado automáticamente el 23 abril 2019.

\section{c) ()우}

Cuadernos LIRICO está distribuido bajo una Licencia Creative Commons Atribución-NoComercialSinDerivar 4.0 Internacional. 


\title{
El mito de la Cautiva: desplazamientos $y$ proyecciones en la literatura contemporánea argentina.
}

\author{
María A. Semilla Durán
}

1 Releer el pasado en tanto Historia, pero también -o paralelamente- releer la literatura del pasado en función de la relectura de la Historia, implica una reflexión que debe desplegarse en varios niveles simultáneos y específicos, tales como las modalidades de narración literaria de la Historia, y por ende la relación entre literatura e historiografía ; la construcción de la memoria, y las relaciones de divergencia, adición, distorsión, desplazamiento o ampliación que el retorno sobre los textos puede aportar a las lecturas originales, así como la definición del lugar del presente desde el cual se lo relee; de los horizontes imaginarios y las subjetividades actuales que entran o no en conflicto con las ya establecidas. En mi tentativa de atravesar esta serie de dificultades de pensamiento y de reformulación, partiré de unas palabras de Marisa Moyano que plantean con gran claridad uno de los marcos de reflexión pertinentes y al cual adherimos totalmente :

« A lo largo del siglo XIX los procesos de territorialización y apropiación discursiva del espacio en Argentina fueron configurados desde procesos escriturarios y desde interacciones discursivas que instituyeron performativamente un proyecto de país, de Estado y de Nación, definiendo el « cuerpo de la patria y sus límites, su territorio y su identidad, lo que debía formar parte de ese cuerpo y lo que no, su política de inclusiones y de exclusiones bajo el conjuro de una idea de lo que debía ser «la Nación ${ }^{1}$ »

2 La cita anticipa además un concepto cuya representación metafórica está en el centro de muchos de mis interrogantes: "el cuerpo de la patria". Y ello porque las primeras representaciones simbólicas del cuerpo de la Patria en la literatura argentina fueron justamente las de los cuerpos de las cautivas, mito fundador de la literatura nacional y a la vez controvertida realidad histórica, que dio origen a un ciclo escritural y discursivo cuyo alcance va mucho más allá de las expresiones canónicas del siglo XIX.

Como ya he escrito alguna vez: 
«En un país en el cual se trata entonces de definir las fronteras que separan la civilización de la barbarie, la modernidad de la tradición y el perfil étnico europeo del fenotipo nativo, - o, como lo demuestra Josefina Ludmer ${ }^{2}$, quiénes serán los excluidos y quiénes los integrados -, el cuerpo de la cautiva, cuyo capital reproductivo está pervertido por la contaminación de la sangre del salvaje, es el lugar simbólico donde se juega el destino de la Patria, porque es en él donde se concentra el drama del mestizaje, de la desterritorialización forzada y de la transgresión extrema ${ }^{3}$.»

El texto inaugural de la serie, y sin duda el que más intensamente ha dejado su huella en el imaginario cultural de la época, es evidentemente La Cautiva de Esteban Echeverría, que funda el paradigma mítico al tiempo que crea, a partir de la inconmensurable ausencia silenciosa de la Pampa, la representación tópica de aquel desierto que se convertiría en un lugar común discursivo, y no sólo en el ámbito de la invención literaria, sino en el de la política, la ideología y la representación identitaria. Como dice Fermín Rodríguez, "Fundar en el desierto, es fundar el desierto en la literatura, convertir esa decepción desnuda de significado en un objeto que pueda elaborarse estéticamente. ${ }^{4}$ Esta actitud constructora de sentido es el inicio de una actividad discursiva sostenida y homogénea, destinada a instalar en los receptores una idea de la identidad imaginada a partir de cortes previos en la sustancia concreta de la Patria, y ello a partir de la ilusión de su preexistencia ontológica, gracias a una operación de naturalización excluyente de las diferencias. La falla civilización/barbarie, que impregnará el pensamiento argentino y latinoamericano desde el siglo XIX estaba ya presente en sus manifestaciones territoriales y étnicas en La cautiva, antes de que Sarmiento la expusiera en toda su rotundidad discriminatoria.

Ello justifica la reflexión de Susana Rotker :

«El pasado debe ser articulado por el presente de la memoria. Toda imagen del pasado que no se reconozca activamente en el presente amenaza con desaparecer irremediablemente (Benjamín). Por eso es responsabilidad del presente estudiar las desapariciones de grupos de personas, de episodios históricos: las supresiones tienen más que ver con la identidad del presente que con la cultura del pasado ${ }^{5}$.

6 Historia que coincide con la que, de manera más general, enuncia Homi Bhabha refiriéndose a la función del crítico: "Debe intentar comprender plenamente, hacerse responsable de los pasados no dichos, no representados, que habitan el presente histórico"6. Dentro de ese doble marco, histórico y teórico, prestamos especial atención a una doble resonancia de la palabra "presente", utilizada tanto por Rotker como por Bhabha: los deseos de olvido del presente a los que alude la primera entran en tensión dialéctica con "los pasados que habitan el presente" del segundo. En ambas casos, la permanencia de un pasado inhibido ejerce su presión sobre la percepción presente ; y cada uno de ellos ilustra una de las posibilidades implícitas en el dilema de la memoria : olvidar para borrar, para hacer, parafraseando a Borges, como si esos aconteceres no hubieran sido; o abrir paso a la pulsión de lo denegado que pugna por emerger y devenir representación, rescatarlo así del silencio, nombrarlo. El mito de la cautiva es un excelente paradigma para analizar esas operaciones de ocultamiento, inhibición, retorno y relectura que desembocan en la reescritura, y que tienden a colmar los "agujeros negros", esos 'consensos oscuros o 'inconscientes', acuerdos para 'barrer' de la memoria pública ciertos 'hechos traumáticos" de los que habla Casas y Chacón ${ }^{7}$. Y esas profusas reescrituras comienzan a producirse en un contexto ideológico e histórico particular: el de la recuperación de la memoria del pasado reciente, que no sólo vuelve visible lo ocultado, sino que obliga a indagar en las raíces del Mal, a situar la serie de eventos que lo preparan 
y consolidan, los discursos que van ilustrando las escaladas de violencia o de rechazo, los designios de los grupos de poder que en cada momento de la historia han conducido esos procesos, los antecedentes concretos que se eslabonan en la cadena de la barbarie hasta alcanzar el nivel de horror experimentado en la década de los 1970. Se genera así un trabajo de relectura de los discursos canónicos, pero también de las representaciones culturales de la identidad, como lo indica Marisa Moyano :

« [...] el reconocimiento de esta incidencia de la praxis discursiva ocupa un espacio central en las producciones culturales literarias y metaliterarias que buscan reconstruir la memoria plural implícita en los huecos y silencios de los relatos de la historia, y como una lámina radiográfica en negativo de los agujeros negros de la tortura, el genocidio y la adulteración de personas e identidades operadas del pasado reciente argentino, se vuelve la mirada hacia la revisión de los procesos discursivos que operaron -a lo largo del siglo XIX en la constitución de los relatos identitarios y alegorías de la nacionalidad'. »

7 Las múltiples variantes del relato de la cautiva no sufren alteraciones notables durante la mayor parte del siglo XIX, en la medida en que la construcción del imaginario colectivo de la nación completa su ciclo de implantación del modelo de república liberal, civilizada, elitista y blanca entre la generación del 37 y la del 80 . También se reproducen los distintos signos, objetos-símbolo o escenas que constituyen el núcleo significativo de los relatos y el germen de los modos estereotípicos que sustentan el canon : el asalto sangriento del malón y el rapto, el alarido del indio, el desvanecimiento de la cautiva, la orgía en las tolderías, la omnipresencia del cuchillo y del degüello, la sombra de las violaciones, la dramatizada victimización de la mujer blanca, la pérdida de la identidad, la llanura sin fin, la amenaza diabólica. Sin embargo, a fines del siglo se producirá la primera brecha en el sistema, con la aparición de la segunda parte del Martín Fierro, La Vuelta (1879). Si bien el tópico del salvaje se mantiene sin grandes variantes, hay dos inflexiones con respecto a la versión clásica del mito : por una parte, se narra la vida del otro lado, generalmente elidida, y ese relato es legitimado por la enunciación en primera persona de un testigo en el interior de la ficción : el desterritorializado Martín Fierro ; por otra, la cautiva, salvada por Martín Fierro, retorna a la civilización, vuelve a atravesar la frontera en el sentido contrario, recupera la humanidad después de haber salvado a su vez la vida del gaucho y haberlo defendido del indio.

8 Habrá que esperar prácticamente hasta mediados del siglo XX para que esta grieta abierta en la frontera por Hernández se ensanche hasta hacerse porosa: dos cuentos de Jorge Luis Borges, El cautivo e Historia del guerrero y la cautiva, desorganizan profundamente el paradigma canónico. No sólo personajes transplantados, desterritorializados, atraviesan una y otra vez, en ambos sentidos, las otrora herméticas fronteras, sino que además, en tanto sujetos libres capaces de redefinir sus pertenencias, eligen integrarse a aquellos espacios geográficos y culturales que no son los de sus orígenes. Eligen, en última instancia, una metamorfosis identitaria, dejar de ser aquellos que fueron para ser otros.

El próximo desplazamiento, radical, con respecto al mito original, será el operado por César Aira en Ema, la cautiva, donde la frontera no es más que un concepto vacío, en la medida en que se la atraviesa y se desplaza continuamente, pero sobre todo en la medida en que se descolocan los atributos que formaban parte de las virtudes y defectos estereotípicos de cada espacio, jugando con sus contradicciones, multiplicando las bifurcaciones y las im-pertinencias, intercambiando las capacidades y las potencialidades, al hacer de los indios refinadísimos estetas decadentes y meditativos, y de los blancos salvajes sanguinarios. 
10 Tratemos ahora, luego de estas consideraciones preliminares indispensables, de ceñirnos al corpus de textos que nos interesan, y que irán emergiendo en los últimos años como otras tantas alternativas de lectura de un sistema simbólico ya atacado en sus fundamentos ideológicos, pero que sigue ofreciendo innumerables posibilidades de interpretación, actualización y discusión. Entre esos textos, que son muy numerosos, nos vemos obligados a elegir algunos, por obvias razones de tiempo y espacio. Contemos entre ellos : La lengua del malón, de Guillermo Saccomano; El placer de la cautiva, de Leopoldo Brizuela, así como algunos otros cuentos de Los que llegamos más lejos ; El año del desierto, de Pedro Mairal, Ya pronto una vaca serás, de Néstor Ponce y El sueño del señor Juez, de Carlos Gamerro.

11 El primer interrogante suscitado por esta enumeración tiene que ver con las razones por las cuales las tramas históricas y míticas tejidas en torno a la figura de la cautiva vuelven a emerger con tanta fuerza y variedad a fines del siglo XX y principios del XXI. Citemos para empezar una reflexión de Ricardo Forster :

« El presente, lo digo de este modo, es el sitio desde el cual el pasado, todo pasado, regresa y cuestiona, interpela y sobresalta nuestras existencias individuales y sociales. Se trata, ahora y ayer, de una interminable querella de interpretaciones que espejan los diferendos políticos, ideológicos, sociales y culturales que nos habitan como sociedad que no puede deshacerse de su pasado como si fuese un lastre que se arroja por la borda. Hablar de acontecimientos pretéritos, propios o ajenos, [...], es hablar de nosotros mismos, de nuestros conflictos y de nuestras tensiones irresueltas; es, desde otra perspectiva, intentar descifrar lo que nos atraviesa recurriendo a enseñazas más o menos lejanas que, sin embargo, constituyen una suerte de referencia capaz de iluminar nuestras vicisitudes contemporáneas. [...] Lo que retorna, cuando retorna, lo hace abriendo brechas en el presente, surgiendo de disputas y necesidades que no están localizadas en un vago e inapresable ayer sino que responden a una realidad, la actual, que a través de alguno de sus sujetos reinstala lo que permanecía olvidado, sepultado o simplemente en una vaga lejanía9. »

12 En palabras de Marisa Moyano, las praxis discursivas que han sustentado nuestra identidad imaginada durante el siglo XIX se han fundado también

«como otros "agujeros negros" de exclusión y olvido que fagocitaron otro genocidio : el que operó sobre los cuerpos de los indios -como el otro más otro ajeno a la Nación, en tanto no-ciudadano de ley, proscripto de voz, tierra y derecho ${ }^{10}$. "

13 Reaparecen entonces en escena los pueblos originarios y las formas históricas de su desaparición programada, que revierten la imagen de la expansión civilizadora del XIX hasta convertirla en masacre indiscriminada motivada por la apropiación de la tierra.

14 Otro espacio de negación ha sido teorizado abundantemente entre los años 1960 y la actualidad, otras minorías subalternas han sido apeladas, se han abierto paso, construido un espacio y liberado sus voces cautivas : las mujeres.

15 La escena del mito de la cautiva es propicia para la exploración de estos dos procesos a la vez de modernización y de memoria, de liberación y de palabra : en ella se cruzan dos categorías históricamente denegadas y, por ello mismo, subversivas, a rescatar : la de los pueblos originarios, la de las mujeres. Proyectar los saberes del presente sobre esos ámbitos conflictivos permite avanzar en la construcción y la formulación de visiones integradoras de la identidad nacional, que produzcan a su vez efectos concretos sobre las políticas sociales y de género pendientes. La revisión de la historia tiende a configurar una memoria plena, en la que todos los protagonistas ocupen el lugar que les 
corresponde, y en el que todas las historias comunitarias o individuales, se entrelacen en la Historia nacional.

En prácticamente todos los textos mencionados se entrecruzan ambas problemáticas, en un marco temporal variable en el cual la mirada presente puede volverse sobre el pasado o el pasado infiltrarse en el presente; y en el que la figura constante del rapto, el cautiverio o la desaparición define una tonalidad, una atmósfera omnipresente, una continuidad histórica y retórica.

Leopoldo Brizuela y Guillermo Saccomano construirán sus representaciones de la cautiva a partir de las nuevas lecturas de género, las tentativas de desplazar los límites - las fronteras - que obstaculizan la libre expresión de los deseos femeninos y su constitución como sujetos autónomos. Si en el caso de El placer de la cautiva (2001) el principio consiste en transplantar al escenario canónico de los fortines una inesperada - y transitoria - toma del poder femenina, más propia de una modernidad inmediata que de fines del siglo XIX ; y en el de Saccomano la de retrotraer la temporalidad de la historia a los años 50 del siglo XX para desnudar la porosidad real de las fronteras sexuales, en ambos casos esas transgresiones se escenifican por contraposición a los cautiverios naturalizados, a la dominación a la que son sometidas las mujeres dentro de la sociedad civilizada, a su reducción al rol reproductor y a la represión de su goce. Si Rosario, la adolescente del siglo XIX creada por Brizuela, avanza hacia su iniciación sexual ofreciéndose a la mirada deseante del indio, también forma parte de su aprendizaje la reflexión sobre las máximas transmitidas por las mujeres blancas de su propia tribu y los tabúes que ese legado impone : « ya que la vida era una guerra, parecía preferible combatir de una vez a todo o nada, antes que seguir pariendo y sepultando en retaguardia con la enloquecedora regularidad de los quehaceres domésticos. ${ }^{11}$ » En cuanto a los personajes de Saccomano, el profesor Gómez y Lía son "cautivos de un secreto ${ }^{12}$ ", el de la homosexualidad; mientras que Delia, la protagonista reconstruida por el narrador, lo es de su condición de esposa de un militar, que descubre en los amores lésbicos con Lía la liberación del deseo. Delia vierte su frustración carnal y afectiva en la escritura de una novela situada a fines del XIX y cuya protagonista, D., es una blanca casada con un Capitán y raptada por el indio Pichimán : «El suyo fue un matrimonio igualitario. Abrirse de piernas, ser penetrada, albergar la esperma fecundadora ${ }^{13}$. » Vemos entonces cómo la construcción de las tramas narrativas desnuda los múltiples cautiverios tolerados - y aun propiciados - por la sociedad "civilizada", y los opone a la libertad de las opciones salvajes. Todo cautiverio, naturalizado o no, clama por la liberación ; toda liberación implica atravesar la frontera de una prohibición, es decir, un gesto subversivo de ruptura, de desterritorialización y de elección, toda reivindicación de lo Otro busca una lengua propia para ser dicha, una lengua bárbara, la lengua del malón. Sean las prisiones simbólicas o reales, sociales o sexuales, institucionales, políticas o étnicas, extraerse de ellas tiene un precio, que puede ser la muerte. Pero también tiene un premio, que es el goce. En los dos textos se pone el cuerpo a disposición de quien no hubiera debido gozarlo y se lo sustrae a los usos " legítimos »; en ambos casos una mujer prisionera de los prejuicios y los tabúes se libera y descubre placeres siempre soñados y nunca alcanzados. Las dos cautivas del XIX se rebelan contra las convenciones y deciden los ritmos de la sexualidad, ambas se sirven del cuchillo para simular el degüello o la castración -simbólicamente equivalentes- antes de poseer y ser poseídas, ambas imponen su ley y ejercen un poder soberano en el encuentro de los cuerpos. Pero Rosario, después de las bodas bárbaras que ella misma ha propiciado, y para las cuales no sólo recorre un camino de educación sexual sino también de 
aprendizaje cultural del mundo del Otro, se ve absorbida por ese mundo sin que esta vez su voluntad pueda ejercerse. Celebrando la unión y mientras el cacique duerme, «los indios tomaron a la muchacha entre sus brazos y entonces, como a todas las cautivas, le arrancaron minuciosamente las plantas de los pies $^{14}$. »

Rosario había decidido jugarse el todo por el todo como una apuesta a la libertad. Esta vuelta de tuerca no sólo deconstruye el relato que acabamos de leer : también, de alguna manera, deconstruye lo que antes habíamos señalado como un progreso operado por los textos de la serie, en la medida en que pareciera que la frontera vuelve a cerrarse, y esta vez excluyendo toda posibilidad de vuelta atrás. El goce celebrado puede convertirse a su vez en cautiverio: probablemente Brizuela sugiera con ese cierre inesperado que los cuentos de hadas no existen, y que la libertad plena del sujeto femenino está aún lejos de ser una realidad.

En el caso de la novela de Saccomano y su compleja estructura en abyme, ninguna de las cautivas puede vivir la vida que ha elegido : D., la protagonista de la novela secreta escrita por Delia, ve morir en manos del Ejército a su amante, el cacique Pichimán, y en un último mensaje a la civilización que acaba de exterminar indiscriminadamente a los indígenas, se corta la lengua con un facón. La lengua como instrumento esencial del placer descubierto en brazos del salvaje y la lengua como nuevo lenguaje capaz de decirlo, de nombrar la nueva identidad como sujeto : la hibridez de la civilizada liberada por la barbarie de sus tabúes y dominaciones. Si la mutilación de Rosario asegura su integración a la cultura del otro, la mutilación de D. afirma el valor de la libertad por sobre el de la vida. Ninguna de las dos sale indemne de la experiencia, pero en ambos casos el umbral, la frontera hacia el otro y hacia la propia construcción ha sido franqueada, la puerta del goce se ha abierto y la conciencia de sí se ha transformado. En ambos casos, la virilización de la mujer ha sido una estrategia de poder, pero también de igualación. En ambos casos es sancionada, sea por los usos comunitarios, sea por la "guerra civilizadora" entre las comunidades.

El espacio "vacío" del desierto del origen ha ido saturándose de sentidos, proyectos y ficciones, la negatividad de la barbarie ha ido modulándose hasta devenir desafío y conquista, lo político sigue impregnando cada ramificación del tronco mítico, y la letra recobra, probablemente, un grado de performatividad semejante al inicial, pero esta vez en el proceso de deconstrucción del mito. La territorialización homogénea deseada y escrita por Sarmiento ${ }^{15}$ estalla en mil fragmentos y se deshace en los cruces. Hay entonces un "salto" que radicaliza de otra manera miradas y lecturas, una metamorfosis de lo que podría ser la nueva biblioteca nacional. Recordemos la reflexión de Lelia Area :

«[...] podríamos afirmar que las relaciones entre historia y ficción son históricas en sí : cambian con el tiempo y con los distintos paradigmas, géneros y/o modalidades discursivas dominantes; y es en y desde la biblioteca donde se exponen y guardan estos cambios ${ }^{16}$.»

21 Justamente ese concepto de Biblioteca nacional como sistema de textos que definen la construcción identitaria y que se asienta en las relaciones históricas entre historia y ficción, relaciones que cambian con el tiempo y según las modalidades discursivas dominantes, es uno de los ejes estructurales de la novela de Pedro Mairal, El año del desierto ${ }^{17}$ (2005). Novela de crisis, novela apocalíptica, novela deconstructora de los mitos nacionales y revisora de la Biblioteca nacional, vemos desplegarse en el espacio textual las dos narratividades convocadas por Lelia Area : la de la historia, la de la ficción, leídas à rebours, y reinterpretadas por una mirada del siglo XXI, la de una mujer, otra María, que desandará los caminos de la Historia desandando al mismo ritmo los efectos de las 
construcciones culturales por ella producidas y sus consecuentes ideologizaciones. La novela se inicia con la crisis económica del 2001, progresivamente asimilada a un fenómeno natural implacable, la Intemperie, que avanza sobre la ciudad de Buenos Aires y la devora. En el plano de los ecos intertextuales, profusamente convocados por Pedro Mairal, está la la famosa frase de Sarmiento que alude al riesgo de que la Pampa avance sobre la ciudad y por ende, la barbarie se trague a la civilización. Esa perspectiva imaginaria que Sarmiento esgrime como una amenaza contra la cual hay que actuar políticamente por todos los medios es literalizada en la novela, en la cual el desierto avanza efectivamente sobre la modernidad, deglutiéndola. Las consecuencias son infinitas y se visualizan esencialmente en el descolocamiento del engranaje temporal de la narratividad canónica, puesto que, a medida que la historia ficcional avanza, la Historia de los acontecimientos retrocede, en un proceso incontenible de regresión hacia las tan anatematizadas formas de la barbarie temida por la generación fundadora del 37. Se produce así un fenómeno particular, que justifica la diferente apreciación de ese viaje retrospectivo, puesto que quienes perciben los hechos y los representan son la mirada y la conciencia de una joven mujer del siglo XXI, que ha asumido su modernidad e independencia, y que lee a cada paso la inadecuación entre ese pasado devenido presente y la propia subjetividad. Enloquecimiento vertiginoso del tiempo, que parece transcurrir hacia los orígenes, como una especie de "viaje a la semilla" cuyo destino final no puede ser sino la nada sin sentido del primer desierto, pero que al mismo tiempo hace lugar a una revisión autocrítica y a menudo carnavalesca del pasado a partir de la experiencia del presente. A lo que se suma el desfase entre una conciencia que adelanta con respecto al tiempo en el que va "cayendo" la vida ; un saber que trasciende las experiencias concretas y el estado del imaginario circundante, incluidos los proyectos políticos y el horizonte de expectativas ideológico. La distancia entre la percepción que la narradora tiene de las etapas históricas atravesadas y las escrituras previas de esa Historia, que la novela a su manera desescribe, no sólo abre una brecha crítica entre la historiografía y su lectura, sino que se autoriza una puesta en perspectiva especular entre distintos hechos, que pasan a formar parejas analógicas en las cuales unos tiempos se reflejan en otros, en una suerte de puesta en abismo que vehicula una lectura alternativa y, esta vez, cultural.

La caricaturización del mito literario es flagrante en la descripción carnavalesca del indio, tatuado, vestido con shorts y ojotas, y a menudo impotente. La toldería, por otra parte, se parece menos a las representaciones habituales que a un vaciadero urbano o a las villas miserias que invaden las avenidas porteñas. Tanto el indio como el poblado indígena son objetos temporales y materiales híbridos, en los que se superponen signos de la historia recuperada y de la modernidad derruida. Residuos epocales, mitos degradados, colisiones simbólicas: la escena y sus personajes no están muy lejos del "cambalache» discepoliano.

23 Y las cautivas actuales de los indios, sometidas a sus malos tratos, expresan por boca de María deseos que evocan a otras cautivas argentinas, del siglo XX esta vez, ya no raptadas por los indios bárbaros, sino por los bárbaros militares de la dictadura de los 70 : " $\mathrm{Si}$ hubiese tenido alguna forma de suicidio rápido, una pastilla de cianuro o algo así, la habría tomado ${ }^{18}$

En esa lectura confluyen la relectura de la Historia y la de la Biblioteca nacional: las alusiones, interferencias o intrusiones de textos de Echeverría, Sarmiento, Mansilla, Arlt, Cortázar, Aira, Saer, Brizuela y otros tantos escritores argentinos en el cuerpo del texto de Mairal dan cuerpo a esa otra nación ficcional constantemente solicitada como 
entramado cultural que ha alcanzado su propio grado de consolidación y puede ser resignificado por una lectura paródica en la que el desengaño desnuda todas las ilusiones.

Dos cautiverios afronta María : el primero es el de los indios braucos, luego vendrá el de los indios ú, que más que cautiverio es un refugio y se convertirá transitoriamente en un hogar.

Los braucos vendrían a ser los herederos en el presente de los indios bestiales descritos por Echeverría o por Hernández. Si embargo, hay diferencias entre los unos y los otros, en la medida en que los raptores de María presentan un significativo perfil híbrido, imposible en la época de las fronteras herméticas de los inicios del mito. Como ya lo he dicho en otro trabajo,

"El indio es una mezcla de «salvaje » tópico del siglo XIX y de «barra brava » del siglo XX, es decir, una forma de representación alegórica, contaminada, diforme de la marginalidad, que el «indio puro» representa en el pasado y los habitantes excluidos de los suburbios en el presente. Lo que Mairal ofrece es una imagen condensada de los rasgos comunes de lo que la sociedad «civilizada " rechaza, y ello produciendo una aleación insólita entre diferentes momentos de la Historia : en lugar de sucesión hay superposición, coexistencia, pero lo que sugiere el autor es que son siempre los mismos, bajo sus formas sucesivas, los que ocupan el mismo espacio social." ${ }^{19}$

María, despojada de identidad por el indio, pasa a ser la figura emblemática de La Cautiva, el personaje mítico de la literatura, una suerte de ícono cuya trayectoria ya está trazada. Sin embargo, en el interior de esa figura que hubiera debido ser la víctima por excelencia, se elaboran las respuestas de una mujer alerta: no hay en ella ni sacrificio ni renunciamiento, sino estrategia: "Tenía que obedecer todo lo que me dijeran, no hacerlos enojar, que no me rompieran las piernas, ni me despellejaran los pies. Después me escaparía de alguna forma. ${ }^{20}$ "

Frente a esa línea directriz asumida por una mujer que aúna intuición y racionalidad, la carnavalización de la figura sexual del indio, que de violador brutal se convierte en eyaculador precoz, pone decididamente en cuestión los estereotipos de la virilidad bárbara e invierte los lugares del poder. María no es liberada sexualmente por el cautiverio, como ocurría en cierto modo con Rosario y D., ni es mutilada como ellas. Si Rosario no podía volver a andar y D., al cortarse la lengua, renuncia a la palabra que no puede decir antes de morir -la de su amor y su deseo por el indio-, la María de Mairal camina de otra forma, y cada paso evoca su experiencia. No pierde el órgano físico que es la lengua, pero sí pierde durante los primeros años de exilio en un país lejano, el uso del lenguaje y especialmente el ejercicio de la lengua materna. Cuando los recobra, puede contar, dar testimonio : "Y es como volver sin moverme, volver en castellano, entrar de nuevo a casa. Eso no se deshizo, no se perdió ; el desierto "no me comió la lengua $a^{21}$ " Huellas, marcas de las transfiguraciones, las identidades y los territorios atravesados : la María de Mairal se construye como una síntesis de la historia y de la literatura argentinas, integrando todas las crisis y todos los rostros, haciendo propia cada vez la máscara o el estereotipo para modularlo a su manera, para penetrar en los sentidos de lo ajeno e incorporarlo, para absorber las experiencias y legitimarlas, sea cual sea su precio. Vivir entre, vivir con, vivir como el Otro. Lo que María tendrá finalmente para contar no serán sólo los avatares de su caída en la Historia y sus cautiverios, sino la crisis final de una supuesta civilización blanca que ha superado ampliamente la igualmente supuesta barbarie de los indios. 
29 La estancia de María -rescatada de entre los braucos, en la tribu de los indios ú es un momento reparador que la acerca a una nueva forma de sabiduría. Los ú no son sus captores sino sus custodios : tienen que cuidar de ella hasta que vuelvan a buscarla. Lejos de la intemperie que asola la ciudad natal, María "había encontrado un lugar donde quería quedarme ${ }^{22}$ [...] El tiempo se dejaba habitar. El pasado no dolía. Podía vivir en esa especie de eternidad ${ }^{23}$ ".En ese lugar textual donde resuenan con fuerza los ecos de El entenado de Saer, la utopía ahistórica del mestizaje parece finalmente no sólo posible, sino realizada. Pero los ciclos de la guerra se reanudan, y María es solicitada por la tribu para cumplir el rol inverso de la Malinche : decididos a conducir un último ataque contra los blancos de la ciudad, María será la traductora de los ú ante su propio pueblo. La escena de la Conquista parece haberse invertido, los aborígenes estarían recuperando sus tierras originarias y expulsando al blanco de sus territorios, En realidad esa última y frustrada intervención en la Historia será la prueba definitiva de la inversión de la metáfora identitaria construida por la sociedad blanca. Los ú perderán la guerra ; serán, como en la Historia real siempre viva en este presente caótico y fatal, vencidos por los blancos quienes, atrincherados en el último fortín - la torre Garay, la torre de cristal donde trabajaba María al principio de la novela- revelan su verdadera naturaleza bárbara, Al volver a cruzar la frontera, de retorno a la sociedad civilizada, María, herida en una pierna y apresada por sus ex compañeros de trabajo como trofeo de guerra, descubre que se han convertido en caníbales que se comen los unos a los otros para sobrevivir. Cuando al final del libro María es evacuada hacia las naves que finalmente la llevarán a Europa, en un simulacro invertido y esperpéntico del desembarco del descubrimiento, las últimas huellas de lo que fuera la invasión civilizadora se derrumban : « No se veía la torre por ningún lado, sólo se veía la franja de tierra en el horizonte, sin puntos de referencia, cada vez más delgada.[...] Cuando volví a mirar, ya no se veía la tierra, sólo el agua alrededor. »

30 El siglo XIX y el siglo XXI convergen en un punto de la Historia y se desmienten mutuamente: ni la épica de la Conquista ni la ilusión globalizadora han civilizado el mundo ; los caníbales no son los que Occidente ha designado, y las barreras étnicas no han sido superadas en dos siglos, aunque las sucesivas travesías de las fronteras hayan demostrado que las alianzas son posibles. No hay filiación viable del mestizaje en una sociedad abierta, y las deudas del pasado no sólo no se han saldado, sino que se multiplican. Mairal no cree en la redención, ni perfila el mundo nuevo que podría surgir después del fin del mundo viejo. Pero María cree en la memoria, el lenguaje resucita y la resucita, une sus dos mitades.

31 La novela de Mairal, al jugar con la doble imagen del indio producida por la cultura occidental: el bárbaro irredento, representado por los braucos; la del buen salvaje, encarnada en parte en los indios ú, permite multiplicar los puntos de vista y las imágenes de los pueblos originarios y la reflexión en torno al lugar que ocupan. Ese será el eje de la novela de Néstor Ponce, Una vaca ya pronto serás. La figura del indiecito Cipriano, adoptado por los salesianos, máscara del personaje histórico Ceferino Namuncurá, y presentido como un futuro predicador de la Iglesia ante su propia comunidad, es central, así como su perspectiva de sujeto desgarrado entre dos mundos y dos culturas contradictorias, y las diferentes lecturas institucionales y eclesiásticas de la empresa de recuperación de la que el Vaticano lo hace objeto. Pero la resolución de la historia de Cipriano difiere de manera radical, en la medida en que en la realidad histórica Ceferino muere tuberculoso y abandonado en un hospital romano; mientras que Ponce, reivindicando su derecho a la ficcionalización, lo hace volver a su tierra y optar por otro sacerdocio : se convierte en el 
machi de lo que resta de su comunidad, un machi no sólo homosexual, de acuerdo a la tradición, sino travestido ;

« [...] Cuando lo vi surgir de la tienda de cuero. Embutido en un vestido de raso, escotado y con breteles delgados, los pies en sandalias negras de taquito fino, muy maquillado, los labios anhelantes y los ojos exangües en el trance de un brillo, cuando lo vi así, tuve ganas de llorar ${ }^{24}$. »

Y con ello, el proyecto institucional resulta totalmente subvertido, y la reivindicación de la opción identitaria del "indiecito santo" devenido en machi queer dinamita las coordenadas originales y desnuda la otra ficción : la de la versión supuestamente histórica de los hechos instalada por los aparatos de comunicación de la Iglesia y sus artefactos auxiliares, como la biografía de Manuel Gálvez ${ }^{25}$, cuya propia versión ficcional contradice y cuestiona.

Volviendo al eje de nuestra reflexión, el mito de la cautiva, vemos también una inflexión considerable en el texto de Ponce, puesto que lo que se pone en primer plano es un desdoblamiento de la figura : por una parte la Cautiva Mítica, que retoma, invirtiéndola, la representación borgiana de la cautiva inglesa y rubia, prácticamente convertida en objeto sagrado de deseo y de contemplación fascinada, más allá del uso que de su cuerpo pueda hacer el cacique :

«Mi padre se movía alrededor de la cautiva inglesa, de rodillas, invariablemente de espaldas, las manos sobre el regazo, los largos hilos de la melena rubia brillaban, transparentes. Le caían hasta la grupa. Él andaba a lentos trancos sordos por el piso duro, se le agrandaba la boca, la acechaba, la rodeaba, como yo acechaba allí plantado en medio del frío que crecía por todas partes, la aparición de la bestia ${ }^{26}$. »

Por otra parte, señalamos el salto al primer plano textual de los otros cautivos, los cautivos étnico-sociales : los indios capturados y destinados al trabajo esclavo, las indias jóvenes a quienes se atribuirán los trabajos domésticos en casas de las familias acomodadas, cuyos cuerpos serán impunemente abusados por los hijos y padres de familia, y que serán a menudo exhibidos ante los visitantes como curiosidades antropológicas. La diferencia entre ambas formas de cautiverio es flagrante : frente a la cautiva rubia santuarizada en la tienda del cacique e inaccesible aun a las miradas de los otros, reservada para misteriosas ceremonias eróticas - misteriosas, al menos, para el niño Cipriano que espía por un agujero y gracias a quien accedemos a esas escenas- , la denigración en su ser mismo y la explotación económica de las miembros de las poblaciones originarias sobrevivientes es una vez más el espejo invertido de la dicotomía sarmientina. Pero la indagación del sentido histórico de tales desplazamientos de población y de las utilizaciones productivas de los cuerpos no se agota en ese replanteo de la contradicción civilización-barbarie. También se proyecta de manera flagrante hacia el futuro del siglo $\mathrm{XX}$, y ello tanto en función de las analogías que se pueden establecer entre las escenas históricas, como en la selección precisa de ciertas palabras resignificadas para siempre por los traumas históricos contemporáneos, y que tiñen retrospectivamente los horrores secretos del XIX :

«[...] los caciques y capitanejos sobrevivientes van a ser deportados a Martín García, en el patíbulo de la ciénaga, las alimañas y la viruela. A morir allí. [...] Las madres jóvenes van a ser colocadas en los hogares bien de Buenos Aires [...] los hijos van a ir a estancias por los alrededores de Rosario, de Córdoba, de Paraná. Familias extraviadas, tribus confundidas. Las indias van a ir a reclamarle un día al gobierno por los suyos, como locas van a ir a golpear puertas de ministerios y se van a guarecer de la expectativa en la Recova [...] Cuando llueva se van a poner sobre las 
crenchas un pañuelo blanco, Y van a dar vueltas a la plaza, arrastrando las patas cuadradas... [...] Reclamando por los suyos ${ }^{27}$.» servidumbres, exterminios y control político y productivo de los cuerpos de los indios en el XIX, el genocidio inaugural de la nación, amputada de sus miembros originarios; y las dictaduras del siglo $\mathrm{XX}$, que utilizaran procedimientos semejantes para eliminar a otros enemigos bárbaros, los subversivos, miembro infectado y condenado a la extirpación violenta. En ese caso hablamos de la resonancia constante del pasado en el presente, sus ecos y prolongaciones, sus repeticiones y sus variantes, sus núcleos inamovibles de poder. Al mismo tiempo, la ficción declina una escena inherente a las virtualidades del pasado, viendo en los familiares de los cautivos indígenas, cualquiera fuera su género, una incrustación de imágenes de un pasado mucho más reciente, y haciendo de ellos, al mismo tiempo, una reverberación y un anticipo de las marchas de las Madres de la Plaza de Mayo en el siglo XX. Tales filiaciones analógicas de la Historia se fundan paradójicamente en una suspensión de la dinámica temporal, en la que el transcurso no se niega, puesto que hay un pasado y un presente ; pero al mismo tiempo se desmonta la lógica de la sucesión que lo sostiene, porque las escenas se definen las unas a las otras en una simultaneidad que la Historia produce - la memoria viva- y que desborda la lógica de la temporalidad. Todo está sucediendo en un mismo instante, los exterminios y sus secuelas no afectan a los mismos protagonistas, pero en cada instancia se abaten sobre los que obstaculizan los intereses de ciertos núcleos invariables de poder, trazando una figura constante. La colisión deliberada de escenas distantes, la penetración de unos tiempos en los otros, la intrusión de ciertas palabras marcadas en los relatos que todavía no las habían producido y que, al instalarlas, los transforman releyéndolos y los releen reescribiéndolos. invertir las versiones construidas desde los espacios de poder político y discursivo, ampliar las voces de las comunidades discriminadas y responder al reclamo actual de respeto de las minorías. El conjunto de los actores históricos representados en el marco de una tentativa efectiva de contextualización que no excluya ni actos ni actores, que no censure ni distorsione; que, incluso, cuestione constantemente los poderes establecidos de la razón frente a los desoladores resultados históricos de algunas de sus aplicaciones, hace que estos textos adquieran nuevas performatividades y desempeñen un papel importante en la redefinición de identidades.

Trazar «el mapa de la patria », como ya hemos visto, era para los escritores de la generación del 37, establecer una «identidad nacional civilizada». Podemos decir sin temor a equivocarnos que las relecturas contemporáneas del mito de la cautiva y los relatos relativos al genocidio de las poblaciones indígenas desmontan ese constructo identitario mostrando su doble reverso : por un lado la barbarie concreta y actuante del " civilizado ", que postula la supremacía de la razón para ejercer la supremacía de su razón; por otra, las prácticas de las culturas originarias, negadas como tales, y su vertiente onírica, profética, mágica. Nuevos mapas fragmentarios de una razón atravesada por lógicas alternativas pugnan por emerger y organizarse, y con ellos nuevas interpretaciones, imaginarios e identidades que buscan un lugar donde afincarse, un espacio en el cuerpo de nuevo incompleto de la Patria que los acoja, los reconozca y les haga justicia.

$\mathrm{Si}$, como sostenemos desde el principio, relectura implica reescritura, no solamente se trata de resignificar los paradigmas ideológicos o los imaginarios construidos por las 
élites dirigentes, sino también los textos que los han encarnado y provisto de figuras precisas y simbólicas incorporadas a la tradición nacional. Volver a ponerlas en escena, dialogar con ellas, cuestionarlas, darlas vuelta, travestirlas es una de las prácticas intertextuales que podemos rastrear desde Aira en adelante, prácticamente en todos los autores a los que nos hemos referido. Ya se trate de la ironía, de la deliberada incongruencia entre los espacios y las conductas, de la anacronía o de la repetición en sus variantes más distorsionadas o irreverentes, el corpus provisto por el canon de la literatura nacional es sujeto a formas diversas de violencia textual.

Probablemente sea Carlos Gamerro, en El sueño del señor juez, quien lleve más lejos esa carnavalización que modula todos los grados de la farsa, el grotesco y la caricatura, Para ello se sirve también de la figura del sueño, que no es ya el trance ritual de la visión profética instalado por la perspectiva del indio, sino el delirio catártico que lleva hasta sus últimas consecuencias una trama de mitos y prácticas históricas reconocibles. El autoritarismo, el patriarcado, la violencia política o doméstica y el disciplinamiento de los cuerpos son literalmente deglutidos por «esa erupción general en la cual todo orden había sido trastocado ${ }^{28}$ ", por ese extravío colectivo que se instala como un segmento irreductible y recurrente de la realidad y deviene un dispositivo justiciero que, al invertir las jerarquías, los poderes, los lugares, los géneros y los signos subvierte el esquema dominante del orden basado en el castigo. La ruptura de todas las fronteras, la dimisión de toda censura, la posibilidad de todos los tránsitos socava la figura de la autoridad fundada en la fuerza; y la represión, encarnada en la figura del juez convertido en un amasijo grotesco de plumas, harinas y miel, deja lugar a una libertad orgiástica, en la que todo gesto inhibido se expresa :

«[...] en este revés de la trama del mundo todos los hilos estaban confundidos y en el azar de su desorden formaban figuras que la mente rechazaba con pavor; pero no había en toda esa desaforada, entreverada, rugiente multitud nada más grotesco e incongruente que el montículo de engrudo y plumas que avanzaba de espaldas por un mundo entregado por fin a la locura que hasta esa noche había estado agazapada en los bordes, esperando ${ }^{29}$.»

Tal reivindicación de lo colectivo, lo irracional, el exceso, el desborde, la confusión y el desorden produce una escena radicalmente opuesta al vacío inicial al cual aludiera Sarmiento y que la literatura y sus estrategias discursivas debían subordinar a la Razón, presentándose "como el despliegue posible de llenar con palabras ese 'vacío' en su intento de apropiación ${ }^{30}$ " y desmantela ciertos imaginarios controlados y de control que comienzan a instalarse desde los orígenes de la nación independiente. Gamerro retoma, por otra parte, secuencias canónicas como la del viaje hacia el desierto, tratadas ya por Aira, cuyo viajero es un científico europeo, por Saccomano y Mairal, desde la perspectiva de la cautiva a quien se conduce a la toldería; por Brizuela [1] y Ponce, a través de la mirada de los curas que encuadran la "apropiación" de Ceferino/Cipriano, y, por supuesto e inicialmente, por Hernández en el final de La Ida del Martín Fierro, donde se evoca la experiencia del cristiano refugiado entre los indios para huir de la arbitrariedad de la justicia civilizada. Es justamente ésta última figura la que reescribe Gamerro, al narrar la historia de Rosendo quien, acosado por el Señor Juez, franquea el umbral de la "nueva frontera" constituida por la famosa zanja de Alsina en construcción en los años1876-1877 (“Un foso corta a lo ancho un continente. ¡Un continente! Del lado de acá, está la civilización, o sea nosotros; del lado de allá, la barbarie, o sea ellos [2]") en busca del rastro de los indios a quienes piensa solicitar hospitalidad. El episodio trabaja intensamente, una vez más, en el desmantelamiento del mito canónico, y ello recurriendo 
a diversas estrategias. La primera consiste en replantear la condición del indio en la época, es decir en recontextualizar las representaciones del Otro. Lo que Rosendo encuentra más allá del límite de esa frontera que se desplaza con la Historia, no son las tribus salvajes y brutales descritas por "La Cautiva" de Echeverría, potentes en el combate y la sexualidad, cuyos cuerpos y actos son condensados de energía animal, sino una tribu diezmada por el aislamiento y la malnutrición, monstruosa [3] a fuerza de privaciones, mirando con codicia los caballos del viajero que podrían mitigar su hambre pero sin fuerzas para acometer la tarea de faenarlos. En los años 1876-77, en vísperas de la gran Campaña Exterminadora del desierto, el indio salvaje ha sido ya reducido a la penuria y comenzado a extinguirse sin remedio. El fugitivo -el renegado- tan presente en la Historia [4] y en la literatura- no sólo no será protegido por los indios sino que deberá hacerse cargo de ellos, suministrándoles progresivamente su propia manada de caballos para evitar que mueran de hambre. Los indios bárbaros se convierten así en poblaciones carenciadas que requieren asistencia, el terror que supuestamente debían producir se convierte en piedad. Allí donde la fuerza del otro debía rescatarlo del peligro que lo acecha, Rosendo tiene que recurrir a la propia para organizar una operación de salvataje. Los lugares y las funciones se invierten, y ello no sólo en la relación existente entre el gaucho y ese Otro, sino también en el interior de la representación del blanco, que de agente exterminador se convierte en protector. Los primeros intercambios de Rosendo con los miembros de la tribu no es establecen, además, con los indios mismos, sino con dos cautivos homosexuales - lo que, como ya lo había hecho Aira en Episodio de un pintor viajero [5], no sólo perturba las representaciones de género sino que desplaza también la figura de la mujer víctima reemplazándola por la del barragán consintiente.- y que se disputan de manera indigna la posibilidad de salvarse gracias al forastero. El Cacique está ausente, y en su lugar es la Cautiva quien rige los destinos de la tribu, cautiva española letrada, que ha sido actriz de teatro en su vida anterior al cautiverio[6], y que aparece revestida con los atributos del poder ceremonial ante los ojos atónitos de Rosendo:

« Era también cautiva, descubrió con sorpresa, a pesar del nombre y de la tez oscura

y del enjaezado de plata que le cubría del cabello a los tobillos el cuerpo ${ }^{31}$. »

$41 \mathrm{Si}$, al parecer, en la realidad Baigorria mantenía a la cautiva ataviada lujosamente a la occidental, aquí la cautiva aparece indianizada en su dignidad soberana, y se reitera en ella el rasgo que venimos señalando casi en cada una de las variantes del personaje de la cautiva : una lengua híbrida, una lengua compuesta de elementos disímiles, pero que no sólo le permite comunicarse con Rosendo sino convertirse, a la manera de la Scheherezade de Las mil y una noches en su iniciadora a los placeres de la literatura (contándole las historias de las piezas dramáticas que ha representado en el pasado) y también, de manera indirecta, a la experiencia de la homosexualidad cuando propicia la incorporación del barragán cautivo a sus juegos eróticos. Si Martín Fierro era redimido por el rescate de la cautiva y el duelo con el indio, que de alguna manera legitiman su regreso a la civilización y la definitiva recusación de la alternativa indígena, confirmada como ontológicamente bárbara por el crimen del niño, Rosendo lo será por ese contacto con las ficciones dramáticas narradas por la actriz/cautiva, que ha desterritorializado a Shakespeare y Calderón del escenario a la tienda indígena, como, por otra parte, lo hará Brizuela en Inglaterra, una fábula, cuando la actriz inglesa represente al Calibán de La Tempestad delante de los indios de Tierra del Fuego, aquellos mismos en quienes el personaje se habría inspirado, y que resultan en la realidad más próximos - y prójimosque los compatriotas depredadores. 

tiene lugar en la realidad de la ficción, sino que es vehiculada por la narración de un supuesto testigo : uno de los dos cautivos blancos. Este se presenta como víctima de esos actos bárbaros pero en realidad, Rosendo lo sabrá más tarde, el relato es la coartada imaginaria construida por un verdadero renegado que ha traicionado a los suyos y entregado a su madre y hermanas a la lascivia de los indios. Así como con el recurso a la recontextualización, la imagen del indio lascivo y brutal es desmentida, esta vez no por la Historia, sino por un falso relato ideologizado, por una ficción perversa, que se distingue de la ficción literaria, encarnada por la cautiva. Falsear la Historia, sea por abstracción o escamoteo de sus circunstancias, sea por la construcción de relatos míticos orientados por una intención política o económica, conduce al fracaso; hacer de ella objeto de creación artística redime. En ambos casos, la puesta en abismo de la ficción abre el camino a una especie de justicia heterodoxa y correctora, que desestima lar argucias del cautivo abandonándolo a su suerte y articula el castigo del señor Juez a través de lo que bien podríamos llamar la pesadilla perpetua. Ese eterno retorno del pasado denegado aparece así como la realización perfecta del objetivo inicial : recobrar las historias ocultas, reparar las consecuencias de las discriminaciones autoritarias, verse otra vez y de otra manera en el espejo de la Historia.

\section{BIBLIOGRAFÍA}

\section{Bibliografía}

Area, Lelia, « Travesía por la biblioteca de una nación "naciente », Universidad Nacional de Rosario, www.lehman.cuny.edu/ciberletras/v08/area.html

Brizuela, Leopoldo. «El placer de la cautiva », en Los que llegamos más lejos, Buenos Aires, Alfaguara, 2002. 
Casas, F. y Chacón, P. « Los Agujeros Negros » en Página 30. Año 5, № 70, Mayo de 1996.

Forster, Ricardo. "El horror y la mirada en espejo : una estrategia impúdica", Revista Veintitrés, 17 de agosto de 2013, www.veintitres.infonews.com/nota-6883-politica-El-horror-y-la-mirada-enespejo-una-estrategia-impudica.html

Gálvez, Manuel. El santito de la toldería. La vida perfecta de Ceferino Namuncurá, Buenos Aires, Club de Lectores, 1976. Primera edición : 1947.

Gamerro, Carlos. El sueño del señor Juez, Madrid, Veintisiete Letras. 2000.

Ludmer, Josefina. El género gauchesco. Un tratado sobre la Patria, Buenos Aires, Perfil libros, 2000.

Mairal, Pedro. El año del desierto, Buenos Aires, Interzona, 2005.

Moyano, Marisa. "Literatura, Estado y Nación en el siglo XIX argentino : el poder instituyente del discurso y la configuración de los mitos fundacionales de la identidad", en Amérique Latine Histoire et Mémoire. Les Cahiers ALHIM, nº 15, Literatura, Estado y Nación, alhim.revues.org

Moyano, Marisa. "La performatividad en los discursos fundacionales de la literatura nacional. La instauración de la 'identidad' y de los “huecos discursivos' de la memoria", 2004, Espéculo. Revista de Estudios literarios.Universidad Complutense de Madrid, http://www.ucm.es/info/especulo/ numero27/performa.html

Moyano, Marisa. "Facundo : la negatividad de la barbarie y los procesos de territorialización", en Sincronía, revista en línea de la Universidad de Guadalajara, Primavera 2003, Año 8 / Número 26 Marzo-Junio 2003.

Palti, Elías J. en "Releyendo a Esteban Echeverría”, Interpretaciones. Revista de historiografía argentina $\mathrm{n}^{\circ} 2$, primer semestre 2007

Ponce, Néstor. Una vaca ya pronto serás, México, Siglo XXI Editores, 2006.

Rotker, Susana. Cautivas. Olvidos y memoria en la Argentina, Buenos Aires, Espasa Calpe Argentina/ Ariel Ed., 1999.

Saccomano, Guillermo. La lengua del malón, Buenos Aires, Planeta, 2003

Semilla Durán, María A. «Variaciones y recurrencias : el eterno retorno del mito de la cautiva en la literatura argentina », Réécritures I. Les Ateliers du Séminaire Amérique Latine, Milagros Ezquerro et Eduardo Ramos Izquierdo (dir.), Julien Roger (ed.), n 4, Université Paris-Sorbonne, 2010, ISSN : 1954-3239, publication électronique : http://www.crimic.paris-sorbonne.fr/actes/ sal4/sal4.htm

\section{NOTAS}

1. Marisa Moyano, "Literatura, Estado y Nación en el siglo XIX argentino : el poder instituyente del discurso y la configuración de los mitos fundacionales de la identidad", en Amérique Latine Histoire et Mémoire. Les Cahiers ALHIM, no 15, Literatura, Estado y Nación, alhim.revues.org

2. Josefina Ludmer, El género gauchesco. Un tratado sobre la Patria, Perfil libros, Buenos Aires, 2000.

3. María A. Semilla Durán, «Variaciones y recurrencias : el eterno retorno del mito de la cautiva en la literatura argentina", Réécritures I. Les Ateliers du Séminaire Amérique Latine, Milagros Ezquerro et Eduardo Ramos Izquierdo (dir.), Julien Roger (ed.), n 4, Université Paris-Sorbonne, 2010, ISSN : 1954-3239, publication électronique : http://www.crimic.paris-sorbonne.fr/actes/ sal4/sal4.htm 
4. Fermín Rodríguez, citado por Elías J. Palti, en "Releyendo a Esteban Echeverría", Interpretaciones. Revista de historiografía argentina $\mathrm{n}^{\circ}$ 2, primer semestre 2007.

5. Susana Rotker, Cautivas. Olvidos y memoria en la Argentina, Espasa Calpe Argentina/Ariel Ed., Buenos Aires, 1999, p. 21.

6. Citado por Mariana Moyano, "La performatividad en los discursos fundacionales de la literatura nacional. La instauración de la 'identidad' y de los "huecos discursivos' de la memoria", 2004, Espéculo. Revista de Estudios literarios. Universidad Complutense de Madrid, http:// www.ucm.es/info/especulo/numero27/performa.html

7. Casas, F. y Chacón, P. (1996) : "Los Agujeros Negros". Página 30. Año 5, № 70, Mayo de 1996, p. 6.

8. Marisa Moyano, "La performatividad en los discursos fundacionales de la literatura nacional. La instauración de la "identidad" y los "huecos discursivos" de la memoria" en Espéculo. Revista de estudios literarios, op. cit. El subrayado es nuestro.

9. Ricardo Forster, "El horror y la mirada en espejo : una estrategia impúdica", Revista Veintitrés, 17 de agosto de 2013, www.veintitres.infonews.com/nota-6883-politica-El-horror-y-la-miradaen-espejo-una-estrategia-impudica.html

10. Marisa Moyano, "Literatura, Estado y Nación en el siglo XIX argentino : el poder instituyente del discurso y la configuración de los mitos fundacionales de la identidad", op.cit.

11. Leopoldo Brizuela, "El placer de la cautiva", en Los que llegamos más lejos, Buenos Aires, Alfaguara, 2002, p. 37. El subrayado es nuestro.

12. Guillermo Saccomano, La lengua del malón, Buenos Aires, Planeta, 2003, p. 16.

13. Guillermo Saccomano, La lengua del malón, op. cit., p. 123.

14. Leopoldo Brizuela, "El placer de la cautiva", op. cit., p. 72.

15. Ver Marisa Moyano, "Facundo: la negatividad de la barbarie y los procesos de territorialización”, en Sincronía, revista en línea de la Universidad de Guadalajara, Primavera 2003, Año 8 / Número 26 Marzo-Junio 2003.

16. Lelia Area, Travesía por la biblioteca de una nación "naciente", ", Universidad Nacional de Rosario, www.lehman.cuny.edu/ciberletras/v08/area.html

17. Pedro Mairal, El año del desierto, Buenos Aires, Interzona, 2005.

18. Pedro Mairal, El año del desierto, op. cit., p. 220.

19. María A. Semilla Durán, "Variaciones y recurrencias : el eterno retorno del mito de la cautiva en la literatura argentina », ", in: Réécritures I. Les Ateliers du Séminaire Amérique Latine, Milagros Ezquerro et Eduardo Ramos Izquierdo (dir.), Julien Roger (ed.), $n^{\circ} 4$, Université Paris-Sorbonne, 2010, ISSN : 1954-3239, publication électronique : http://www.crimic.paris-sorbonne.fr/actes/sal4/sal4.htm

20. Pedro Mairal, El año del desierto, op. cit., p. 218.

21. Pedro Mairal, ibid, p. 8. El subrayado es nuestro.

22. Pedro Mairal, El año del desierto, op. cit., p : 262.

23. Pedro Mairal, ibid, 162.

24. Néstor Ponce, Una vaca ya pronto serás, Siglo XXI Editores, México, 2006, p. 197.

25. Manuel Gálvez, El santito de la toldería. La vida perfecta de Ceferino Namuncurá, Buenos Aires, Club de Lectores, 1976. Primera edición : 1947.

26. Néstor Ponce, Una vaca ya pronto serás, op. cit., p. 20.

27. Néstor Ponce, Una vaca ya pronto serás, op. cit., p. 247. Los subrayados son nuestros.

28. Carlos Gamerro, El sueño del señor Juez, Veintisiete Letras., Madrid, 2000, p. 128.

29. Carlos Gamerro, ibid, p. 129. El subrayado es nuestro.

30. Marisa Moyano, «Facundo: La negatividad de la barbarie y los procesos de territorialización", Sincronía, Revista electrónica de Estudios Culturales, ISSN-e 1562-384X, №. 1, 2003. www.dialnet.unirioja.es/servlet/articulo ?codigo $=926205$

31. Carlos Gamerro, El sueño del señor Juez, op. cit., p. 91.

32. Carlos Gamerro, El sueño del señor Juez, op. cit., p. 85. 


\section{RESÚMENES}

A través del análisis de varias novelas contemporáneas argentinas que retoman el mito literario de la Cautiva, introduciendo en el relato saberes y experiencias históricas sedimentadas en el presente, nos interesa observar cómo se modifican las lecturas simbólicas de las imágenes tópicas de la Nación, cuáles son las inflexiones que incorporan para colmar los huecos de la representación y qué tipo de imaginario alternativo dibujan en ese proceso de intervención del mito, en el cual anacronismo, analogía y contextualización son procedimientos esenciales.

À travers l'analyse de plusieurs romans contemporains argentins qui reprennent le mythe littéraire de la Captive, en introduisant dans le récit des savoirs et des expériences historiques sédimentées dans le présent, il est intéressant d'observer comment les lectures des images symboliques topiques de la Nation se modifient-elles, quelles sont les inflexions que ces lectures apportent pour combler les trous de la représentation, et quel genre d'imaginaire alternatif se dessine lors de ce processus d'intervention du mythe, où l'anachronisme, l'analogie et la contextualisation sont des procédés essentiels.

Through the analysis of several contemporary Argentine novels which go back to the literary myth of the Captive while introducing in the story knowledge and historical experiences sedimented in the present, it is interesting to observe how the symbolic readings of the topical images of the Nation are modified, what are the inflexions brought by such readings to fill the wholes of representation, and what kind of alternative imagination is outlined during this process of intervention of the myth, where anachronism, analogy and contextualisation are essential devices

\section{ÍNDICE}

Mots-clés: mythe, captive, Nation, mémoire, relecture

Keywords: myth, memory, reinterpretation

Palabras claves: mito, cautiva, Nación, memoria, relectura

\section{AUTOR}

\section{MARÍA A. SEMILLA DURÁN}

Professeur des universités, Université Lumière Lyon 2

marian.semilla@gmail.com 